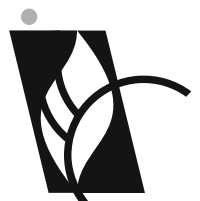

J O U R N A L

$\mathrm{O} F \bullet \mathrm{B} \mathrm{A} \mathrm{L} \mathrm{T} \mathrm{I} \mathrm{C}$

$S$ C I E N C E

E DUCATION

ISSN 1648-3898

Abstract. The purpose of this research is to investigate effect of 5 E learning cycle instruction on 4th grade students' mental ability in the unit of "Introduction to the Matter". The subjects of this study were 160 students from four different classes enrolled to Science Course in an Elementary School in TURKEY. Non-equivalent pre-test/post-test control group design was used. Two of the classes randomly chosen as experimental group (79) took $5 E$ learning cycle instruction, and the other two chosen as control group (81), took traditional instruction. Word-Association

Test (WAT) was administered to the experimental and the control groups as pre-and post-tests to measure the students' mental ability related to Unit of "Introduction to the Matter". The data collected from WAT was converted into mind maps by using content analysis and cut off point methods. As a result of application, while "Introduction to the Matter" subject was seen as a whole on the mind maps of the experimental group of students, mind maps of the control group students were seen to be composed of piecemeal knowledge islets. Hence, it proves that the experimental group students learn terms in a more meaningful and more interrelated way than the control group students.

Key words: $5 E$ learning cycle, mind maps, word association test.

Ibrahim Bilgin Mustafa Kemal University, Turkey

Hümeyra Coşkun

Antakya Anatolian High School, Turkey

Idris Aktas

Mustafa Kemal University, Turkey

\section{THE EFFECT DF $5 E$}

\section{LEARNING CYCLE DN}

MENTAL ABILITY DF

ELEMENTARY STUDENTS

\section{Introduction}

In the educational researches from early history of education until today, "how to teach" subject has been emphasized and different roles have been given to teachers and students. According to the first approaches and methods regarding teaching and learning, while teacher was the one to take an active role and convey knowledge, student was the one to get and storage the knowledge. In the recent researches, student has been taken into the center of learning and teacher has been given the mission to guide (Bodner 1986). In these approaches, student has become an individual searching, observing, questioning, realizing his talents, discovering and learning by doing and experiencing instead of one only listening, taking notes and doing homework. It is thought that learning in such a way prepares the individual for life and teaches him how to learn (Brooks \& Brooks, 1993; Bybee, 2006; Marx et al. 2004; Saribas et al. 2013; Peterson \& Treagust, 1998).

Constructivist approach, which is one of student centered approaches is based on that each new information should be restructured and developed in the light of already existing information on individual's mind and this information should be assimilating obtained by individual. According to constructivist approach, which puts the individual in the center of learning and makes learning a process situation instead of an instant situation, the correctness of student's background knowledge is extremely important. Much information the student learned himself is less accurate than scientific information in point of its rationality, accurateness and generality. Therefore, information that previously learned incorrect or incomplete prevents correctly the assimilation of new knowledge by the student (Brooks \& Brooks, 1993; Gibbons, 2003; Krajcik et al. 1994). 
Application of constructivist approach to a class on science education is submitted in such different ways as learning cycle, four phase learning model, $5 E$ and $7 E$ learning models (Özmen, 2004; Smerdan \& Burkam, 1999). When these application methods are analyzed in literature, it is seen that the approach, also known as "5E Learning Cycle" with 5 phases of Engage, Explore, Explain, Expand and Elaborate is at the forefront and that activities are applied consistent to this model (Lawson, 1995).

In a number of researches, it was determined that lessons taught according to $5 \mathrm{E}$ learning cycle arouse interest in students (Boddy, Watson \& Aubusson, 2003; Clark, 2003), motivate them (Boddy et al. 2003; Wilder \& Shuttleworth, 2004), provide cognitive development (Palmer, 2003; Wilder \& Shuttleworth, 2004), have an impact on understanding cognition (Atay \& Tekkaya, 2008; Stamp \& O'Brien, 2005; Wright, 1995), make students take responsibility and actively participate in lessons (Evans, 2004; Schlenker, Blanke \& Mecca, 2007), make students have pleasure from lessons (Evans, 2004), increase academic achievement (Evans, 2004; Palmer 2003; Schlenker et al. 2007), make students, especially those with low grades increase their interest in lessons and achievement (Demircioğlu, Özmen \& Demircioğlu, 2004). Moreover, Karamustafaoğlu and Yıldız (2006) stated that, in the studies regarding $5 \mathrm{E}$ learning cycle, mostly questions with short answers for knowledge, understanding and application were preferred on the assessment process of the activities. But alternative assessment and evaluation techniques were not utilized on a necessary and intended level.

\section{Word Association Test in Science Education}

When constructivist approach was effectively used in education, traditional assessment techniques have remained capable of revealing the structures of students' minds (Frank \& Barzilai, 2004). Hence, researchers addressed alternative assessment techniques to evaluate the learning process (Gupta, 2004; Hovardas \& Korfiatis, 2006; Nakiboğlu, 2008). Word Association Test (WAT), which is one of alternative assessment techniques, evaluates relationship between cognitive structures besides knowledge, unlike from traditional assessment techniques assessing memorized knowledge such as true/false, twinning and multiple choice tests (Hirsh \& Tree, 2001).

At this technique, student writes the words that are reminiscent of key concepts on any topic. It is accepted that the order of the responses of the student reveals the connections between the words in mind structure and shows semantic relationships of words. According to impact of semantic relationship or semantic distance, it is thought that the closer two words are in terms of semantic distance, the closer relationship between both. As the cognitive search is much faster during remembering, the answer regarding both concepts will be faster (Bahar, Johnstone, \& Sutcliffe, 1999; Wagner, Valencia \& Elejabarrieta, 1996).

WAT is one of the most common techniques that reveals connections of knowledge in student's mind, new knowledge networks and whether the relationships between existing knowledge and new information are meaningful (Bahar et al. 1999; Hovardas \& Korfiatis, 2006). Words are the keywords built on a topic. And also, they are individual's expression of relationships between the key words, which make a subject meaningful in a correct and quintessential way. The number and kind of words that individuals remember when they see the key words, provide information about whether the subject is understood.

WAT is used for many purposes in science education. It was used to detect differences between basic science words being learned in two different societies (Isa \& Maskill, 1982), to investigate the structure of students' knowledge in any topic (Bahar et al. 1999), to determine the conceptual change at the end of the training (Cachapuz \& Maskill, 1987; Hovardas \& Korfiatis, 2006; Nakiboğlu, 2008), to motivate the students and for evaluation of student success (Kostova \& Radoynovska, 2010). Bahar et al. (1999) expressed that WAT is an effective method for revealing the number and type of concepts in mind, also revealing the relationship between the concepts expressed.

In this study, "Introduction to the Matter", the basic subject of science was selected. Previous studies have shown that students have a lot of alternative conceptions on the subject (Krnel, Glažar 
\& Watson, 2003; Krnel, Watson \& Glažar, 2005; Özmen, 2011; Pozo \& Crespo, 2005; Valanıdes, 2000). Alternative concepts about the subject are encountered at all levels of students, even student teacher (Ben-Zvi, Eylon, \& Silberstein, 1986). Subject "introduction to the matter" is taught at all levels of education. The first time students are confronted with this issue in 4th grade. Meaningful and correct creation of these concepts in mind at the beginning of training will prevent the emergence of alternative concepts in the next years. Also, it will provide learning a holistic and meaningful.

$5 E$ learning cycle is successfully applied in many science classes. Its effectiveness was evaluated through the assessment methods such as multiple-choice, open-ended and interview. But there are no studies that reveal structures in the minds of students, the relationships between scientific concepts through mind maps using WAT. The evaluation by means of the word association of $5 \mathrm{E}$ learning cycle will be useful to reveal the integrity of concepts in student's mind.

\section{Research Questions}

1. What is the difference between kind and frequency of the words written for the concepts in pre- and post-WAT by students in the experimental groups?

2. What is the difference between kind and frequency of the words written for the concepts in pre- and post-WAT by students in the control groups?

3. What is the difference between students' mind maps created by using the pre- and post-WAT in the experimental groups?

4. What is the difference between student's mind maps created by using the pre- and post-WAT in the control groups?

5. What is the difference between student's mind maps created by using the post-WAT of students in the experimental and control groups?

\section{Methodology of Research}

\section{Sample}

The sample of the study consisted of 160 4th grade (10 years old) students from four intact classes of science course taught by four different teachers in a public elementary school. Two classes from four classes, randomly assigned as experimental groups, who received $5 \mathrm{E}$ learning cycle, consisted of 79 (33 girls and 46 boys) students. The other two groups, assigned as control groups, who received the traditional instruction, consisted of 81 (36 girls, 45 boys) students. This research model is non-equivalent control group design with pre- and post-tests.

\section{Treatment}

The study was completed within 36 course hours over a 9-week period in elementary schools. WAT was performed in both groups as pre- and post-tests. The researcher explained to the experimental group teachers, how to use teaching materials and introduced the model with a sample lesson plan a week in advance. In the process, some of the courses were observed by the researcher to decrease the effect of the teacher, to minimize any bias, and to increase the effectiveness of the application. Some evaluations of the treatment were done, teachers' problems of the treatment were solved.

Application of 5E Cycle; applying the 5E lessons, teachers and students carried out the following activities. Each level consisted of 18 cycles, and each cycle was completed in 2 course hours. "Introduction to the Matter" unit includes concepts of characteristic properties of matter, states of matter, mass and value, change of matter, change of state and mixture. 
Table 1. Application of 5E Cycle in Experimental Group.

\begin{tabular}{|c|c|}
\hline Phase & Applications \\
\hline Engage & $\begin{array}{l}\text { Teachers tried to shadow the topic with visual samples and applications instead of teaching definitions and } \\
\text { features of some concepts such as substance, volume, mass, solid, liquid and gas directly, }\end{array}$ \\
\hline Explore & $\begin{array}{l}\text { Measurements were performed, their results were interpreted, and unitary transformation was attempted to make } \\
\text { realize with examples from everyday life, matches and using other alternative measure methods thanks to the } \\
\text { activities done one-to-one or in groups instead of solving the problems with the usage of measure units directly } \\
\text { during the course or homework. }\end{array}$ \\
\hline Explain & $\begin{array}{l}\text { Groups, who performed correctly, were applauded by the class, so the success was awarded. In this way, it was } \\
\text { aimed to keep their motives on the subject alive. In an environment provided for the students to learn mixture } \\
\text { making and mixture separating methods through experience, students explained the activities they took part in by } \\
\text { interpreting them in their own expressions. }\end{array}$ \\
\hline Expand & $\begin{array}{l}\text { Applications made and information learned in explanation was applied to other problems in-depth trying to relate } \\
\text { them with the next subject. Applications providing students to relate the information they learned with the next } \\
\text { subject were given as homework on research, on preparing a poster or a project, and were evaluated during the } \\
\text { next course at introduction stage. }\end{array}$ \\
\hline Elaborate & $\begin{array}{l}\text { Prepared according to the assessment methods such as branched tree, structured grid, concept map, puzzle } \\
\text { solving, filling the blanks, matching, multiple-choice questions, true-false type questions, questions with short } \\
\text { answers, interpreting by visual reading on the picture, completing the deficient sentence, completing a story, this } \\
\text { phase was completed within the course hour and student feedback was received. }\end{array}$ \\
\hline
\end{tabular}

Application of the Traditional Method; two classes taking part in the control group of the research were never interfered in, thus teachers used the textbooks prepared pursuant to current education program, and using the teaching methods they chose. During the course, students kept their textbooks and notebooks open. The teacher began to discuss the subject of the day, provided examples on the subject and asked students for their examples. Then he listened the students' examples and saw that always the same students requested to speak. Then the teacher had students take notes in their notebooks on the descriptions and relevant examples of the concepts regarding the subject. This process continued until the end of the unit.

\section{Instrument}

Word Association Test (WAT): In order to address the research questions stated in this study, students in the experimental and the control groups were given WAT as pre- and post-test to investigate their mental ability on target concepts. WAT was prepared by the researcher about the subjects in the "Introduction to the Matter" unit included to the elementary education 4th grade Science course teaching program. To prepare WAT, the researcher determined 20 main concepts on the unit.

The test was evaluated by 4 classroom teachers and 1 science education expert for the appropriateness of the key concepts. 10 key concepts were selected in the direction of the suggestions. Some concepts were excluded from the 10 concepts within the scope of the application. We had to limit the number of key concepts to 10 because 160 students participated while preparing the number of the words, frequencies and cut off points and mind maps in WAT data, which is a qualitative study. Besides, students were given 60 seconds for each word.

- 10 keywords were determined at the second stage:

$\begin{array}{llll}\text { MATTER } & \text { QUALIFICATION } & \text { SOLID } & \text { MEASUREMENT } \\ \text { VOLUME } & \text { RAW MATERIAL } & \text { MASS } & \\ \text { MIXTURE } & \text { SEPARATE } & \text { HEAT } & \end{array}$


The following procedures were carried out after the data analysis for pre- and post-WAT results on the groups separately;

a) Words written by the student were listed and their frequencies were determined. In this phase, similar words were coded with the same code. For example, the word group "equal arm scale" and the word "scale" were united under the title "scale".

b) In order to determine if the words written by the students are relevant to the subject, the researcher and two experts first worked together on the words written by 3 students from each class ( 12 students total) chosen randomly from the experimental and control groups' pre- and post-WATs.

c) At this stage, after reaching a harmony in determining the "relevant" and "irrelevant" words, the words on the word list were coded by the researcher and the expert as "relevant" or "irrelevant".

d) By comparing the codes done by the two coders, similar and different codes were determined. For 10 key concepts held in pre- and post-WAT of the experimental and control groups, 5090 different words were written by the students in total. There was a disagreement between the two coders in 160 and agreement in 4930 of these words. The consensus between the codes was determined by using the formula developed by Miles and Huberman (1994). The formula is:

e)

$$
\text { Reliability }=\frac{\text { Agreement }}{\text { Agreement }+ \text { Disagreement }}
$$

The reliability between the coders was determined as 0.97 according to this formula.

f) 160 words coded differently by the two coders were presented to 2 experts to decide if the words are relevant.

g) The frequencies of the "relevant" and "irrelevant" words were classified (separately for each concept) according to the pre- and post-WAT of the experimental and control groups and displayed in figures.

h) The relevant words were put into one list mind maps created according to the determined cut off point (Bahar, Nartgün, Durmuş \& Bıcak, 2008).

i) Considering the frequencies of the answers given in the experimental and control groups about WAT, the mind maps were created for three different cut off points. The first cut off point of the mind map was determined as 40 , the second one as 30 and the third one as 20. Each of them is shown in a different color: the first is black, the second is purple and the third is blue colors.

\title{
Results of Research
}

\author{
Frequency and Kind of Words Written for the Concepts in WAT
} by Students in the Experimental Group

When the pre- and post-WAT results of the experimental group were compared, it was seen that the relevant word kinds and frequencies increased in all key concepts, while the irrelevant word kinds and frequencies decreased. There are 737 kinds and 2647 frequencies of the relevant words regarding the pre-WAT, and these numbers are 979 kinds and 5079 frequencies in post-WAT. Also there are 716 kinds and 1231 frequencies of irrelevant words in the pre-test, and these numbers are 307 kinds and 540 frequencies in the post-WAT. The frequency and kind of words written for the key concepts in WAT by students in the experimental group are given in Table 2 . 
Table 2. Analysis of the Pre- and Post-WAT for Experimental Group.

\begin{tabular}{|c|c|c|c|c|c|c|c|c|c|}
\hline \multirow{3}{*}{ Num. } & \multirow{3}{*}{ Concept } & \multicolumn{4}{|c|}{ Pre-WAT } & \multicolumn{4}{|c|}{ Post-WAT } \\
\hline & & \multicolumn{2}{|c|}{ Relevant word } & \multicolumn{2}{|c|}{ Irrelevant word } & \multicolumn{2}{|c|}{ Relevant word } & \multicolumn{2}{|c|}{ Irrelevant word } \\
\hline & & Kind & $f$ & Kind & $f$ & Kind & $f$ & Kind & $f$ \\
\hline 1 & Matter & 106 & 335 & 37 & 50 & 155 & 695 & 19 & 26 \\
\hline 2 & Qualification & 42 & 116 & 124 & 196 & 77 & 543 & 45 & 65 \\
\hline 3 & Solid & 91 & 392 & 28 & 47 & 128 & 624 & 12 & 16 \\
\hline 4 & Measurement & 60 & 366 & 38 & 103 & 67 & 513 & 26 & 33 \\
\hline 5 & Volume & 62 & 160 & 78 & 139 & 93 & 461 & 29 & 76 \\
\hline 6 & Raw material & 45 & 158 & 142 & 242 & 64 & 323 & 84 & 112 \\
\hline 7 & Mass & 74 & 287 & 40 & 106 & 99 & 456 & 27 & 78 \\
\hline 8 & Heat & 77 & 379 & 61 & 92 & 88 & 459 & 36 & 59 \\
\hline 9 & Mixture & 116 & 297 & 51 & 77 & 116 & 468 & 17 & 58 \\
\hline \multirow[t]{2}{*}{10} & Separate & 64 & 157 & 117 & 179 & 92 & 537 & 12 & 17 \\
\hline & TOTAL & 737 & 2647 & 716 & 1231 & 979 & 5079 & 307 & 540 \\
\hline
\end{tabular}

Frequency and Kind of Words Written for the Concepts in WAT by Students in the Control Group

Frequency and the kind of words written for the key concepts in WAT by students in the control group are given in Table 3.

Table 3. Analysis of Pre- and Post-WAT for Control Group.

\begin{tabular}{|c|c|c|c|c|c|c|c|c|c|}
\hline \multirow{3}{*}{ Num } & \multirow{3}{*}{ Concept } & \multicolumn{4}{|c|}{ Pre-Test } & \multicolumn{4}{|c|}{ Post-Test } \\
\hline & & \multicolumn{2}{|c|}{ Relevant word } & \multicolumn{2}{|c|}{ Irrelevant word } & \multicolumn{2}{|c|}{ Relevant word } & \multicolumn{2}{|c|}{ Irrelevant word } \\
\hline & & Kind & $f$ & Kind & $f$ & Kind & $f$ & Kind & $f$ \\
\hline 1 & Matter & 94 & 197 & 42 & 74 & 119 & 442 & 32 & 63 \\
\hline 2 & Qualification & 22 & 81 & 103 & 173 & 64 & 357 & 78 & 117 \\
\hline 3 & Solid & 81 & 294 & 37 & 53 & 168 & 680 & 14 & 17 \\
\hline 4 & Measurement & 50 & 258 & 38 & 71 & 57 & 560 & 33 & 45 \\
\hline 5 & Volume & 23 & 39 & 64 & 110 & 101 & 392 & 30 & 77 \\
\hline 6 & Raw material & 24 & 46 & 63 & 80 & 65 & 196 & 77 & 260 \\
\hline 7 & Mass & 46 & 172 & 35 & 55 & 92 & 435 & 30 & 64 \\
\hline 8 & Heat & 52 & 282 & 22 & 24 & 78 & 499 & 50 & 70 \\
\hline
\end{tabular}




\begin{tabular}{|c|c|c|c|c|c|c|c|c|c|}
\hline \multirow{3}{*}{ Num } & \multirow{3}{*}{ Concept } & \multicolumn{4}{|c|}{ Pre-Test } & \multicolumn{4}{|c|}{ Post-Test } \\
\hline & & \multicolumn{2}{|c|}{ Relevant word } & \multicolumn{2}{|c|}{ Irrelevant word } & \multicolumn{2}{|c|}{ Relevant word } & \multicolumn{2}{|c|}{ Irrelevant word } \\
\hline & & Kind & $f$ & Kind & $f$ & Kind & $f$ & Kind & $f$ \\
\hline 9 & Mixture & 56 & 165 & 40 & 51 & 111 & 515 & 41 & 66 \\
\hline \multirow[t]{2}{*}{10} & Separate & 25 & 104 & 69 & 98 & 93 & 435 & 38 & 48 \\
\hline & Total & 473 & 1638 & 513 & 789 & 948 & 4511 & 423 & 827 \\
\hline
\end{tabular}

When the pre- and post-WAT results of the control group were compared, it was seen that the relevant word kinds and frequencies regarding the key concepts used increased and irrelevant word kinds and frequencies decreased, except for the concepts RAW MATERIAL, MASS and HEAT. The irrelevant word kinds for the RAW MATERIAL increased from 63 to 77 and the frequency increased from 80 to 260 . Though the irrelevant word kinds decreased from 35 to 30 in MASS, the frequency increased from 55 to 64. The irrelevant word kinds in HEAT key concept increased from 22 to 50 and the frequency increased from 24 to 70. Also, the total relevant word kinds are 473 in the pre-WAT and 948 in the post-WAT; the frequencies are 1638 in pre-test and 4511 in the post-test. The total irrelevant word kinds are 513 in the pre-test and 423 in the post-test; the frequencies are 789 in the pre-test and 827 in the post-test. The total relevant word kinds and the frequencies increased. However, the irrelevant word kinds did not decrease and their total frequencies even increased.

\section{Mind Maps of the Students Determined Through WAT and Interpretations}

Mind maps prepared regarding the words and frequencies for the concepts written by students in the experimental and control group were drawn separately for the pre-WAT and post-WAT.The mind maps were created according to the three cut off points (CoP): the first CoP with the word frequency 40 and up, the second CoP with the word frequency 30-39 and the third CoP with the word frequency 20-29.

The mind maps of students in the experimental group determined through pre-WAT are shown in Figure 1.

The results in Figure 1 have been interpreted as follows;

a) In the first CoP, 4 in 10 concepts emerged and these concepts were not associated with each other. One word (HEAT-temperature; SOLID-ice) or two words (MASS-kilogram and weight; MEASUREMENT-meter and ruler) recalled of the each concept. The written words are the most commonly used words in daily life.

b) In the second CoP, MATTER concept added to the emerging concepts in first CoP. A word also added to each of the first concepts. The MATTER and SOLID concepts were associated with each other. Liquid and gas words associated with the MATTER concept have emerged. So that MATTER concept has associated with the three state of matter; solid, liquid and gas. Also the MEASUREMENT and MASS concepts were both with the kilogram word.

c) In the third COP, 8 in 10 concepts have emerged by adding RAW MATERIAL, QUALIFICATION and SEPARATE concepts. And also the branching increased by adding the new words to the concepts. Words have been associated with concept are frequently used in daily life. Words associated with concepts to be noted that the words used interchangeably in daily life such as MASS-weight, HEAT-temperature, SEPARATE-divide and QUALIFICATION-feature. 
Mind maps of students in the experimental group determined through the post-WAT are shown in Figure 2.

The results in Figure 2 have been interpreted as follows;

a) In the first CoP, almost all of concepts (9 in 10 concepts) emerged and VOLUME, MEASUREMENT and MASS were associated with each other; also MATTER and SOLID were associated. The concepts associated with more than one word.

b) b) In the second CoP, a new concept wasn't added but the number of words associated with concepts has increased. The QUALIFICATION and SEPARATE concepts associated with each other through magnetization. Words associated with the concepts reflected feature or state or example of the concept.

c) c) In the third CoP, all of the concepts emerged and all the concepts but HEAT and MIXTURE have associated with each other to the integrity between the concepts. The numbers of scientific words associated with the concepts have increased, reaching 7 or 8 numbers.

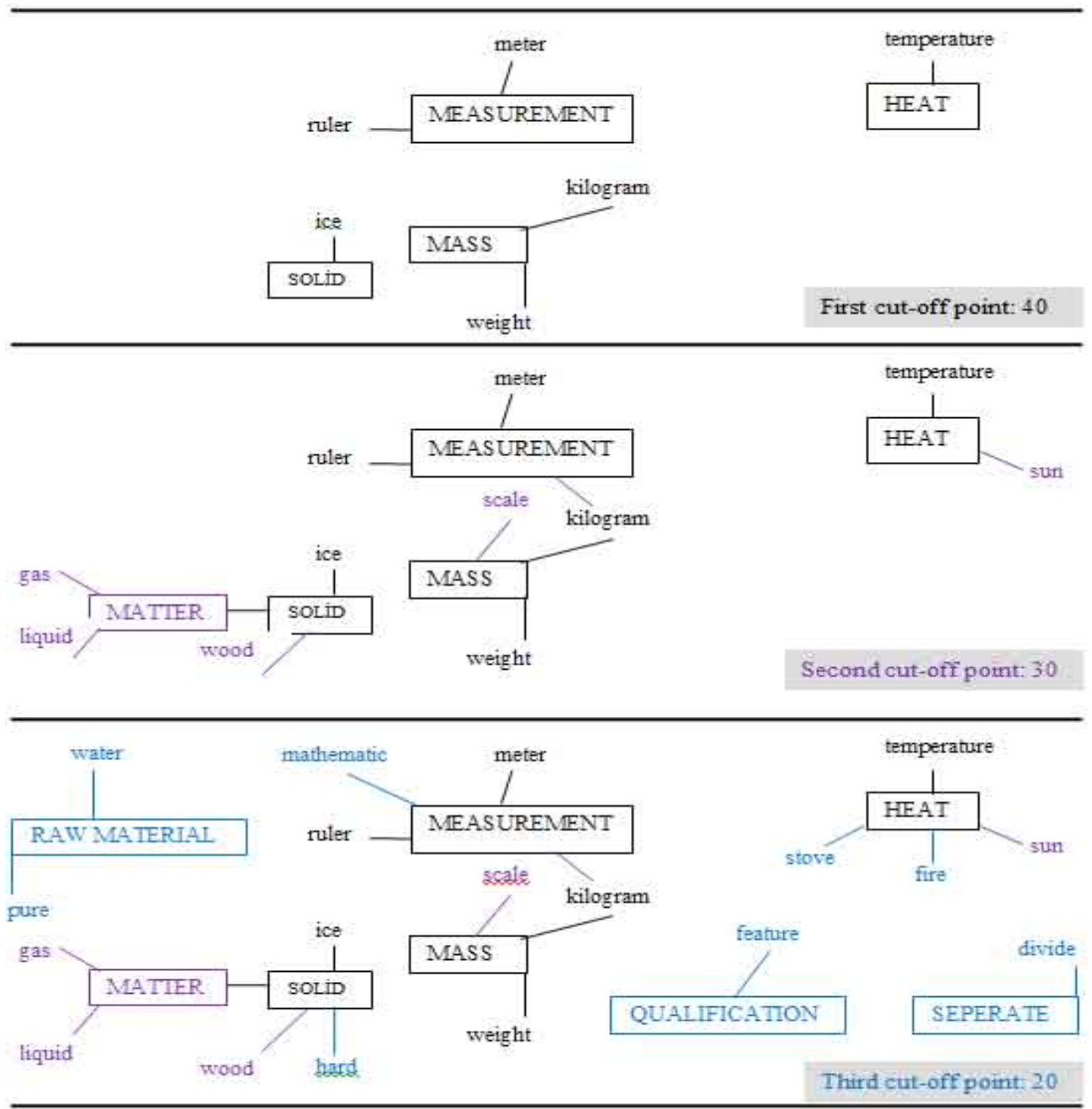

Figure 1: Mind maps of students in the experimental group determined through the pre-WAT.

The first CoP in the post-WAT has raised more concepts than the pre-WAT and in all CoP. The numbers of concepts associated with each other and the number of words associated with concepts in the post-WAT were higher than in the pre-WAT. The words in Post-WAT were more scientific. The MATTER 
and MASS concepts and the MEASUREMENT and MASS concepts which associated with each other in the second CoP of the pre-WAT were associated in the first CoP of the post-WAT. In the mind map of post-WAT, 8 of the 10 concepts used in the WAT were linked together with their branches.

The VOLUME and MIXTURE concepts which did not appear in pre-WAT have emerged in first CoP in post-WAT. The RAW MATERIAL concept appeared for the first time under the third CoP in the mind map with the words petrol, worked matter, matter.

The misconceptions emerged in first CoP in pre-WAT more late emerged the third CoP in post-WAT (as MASS-weight; RAW MATERIAL-water).

Irrelevant words which emerged in pre-WAT were not observed in the post-WAT such as SEPARETEdivide and it was associated with more correctly and high frequency words in post-WAT such as sieve, filter, flotation, and evaporation.

The QUALIFICATION concept, which was branched with the words colour, hard, soft, smell, feature and solid were attained.

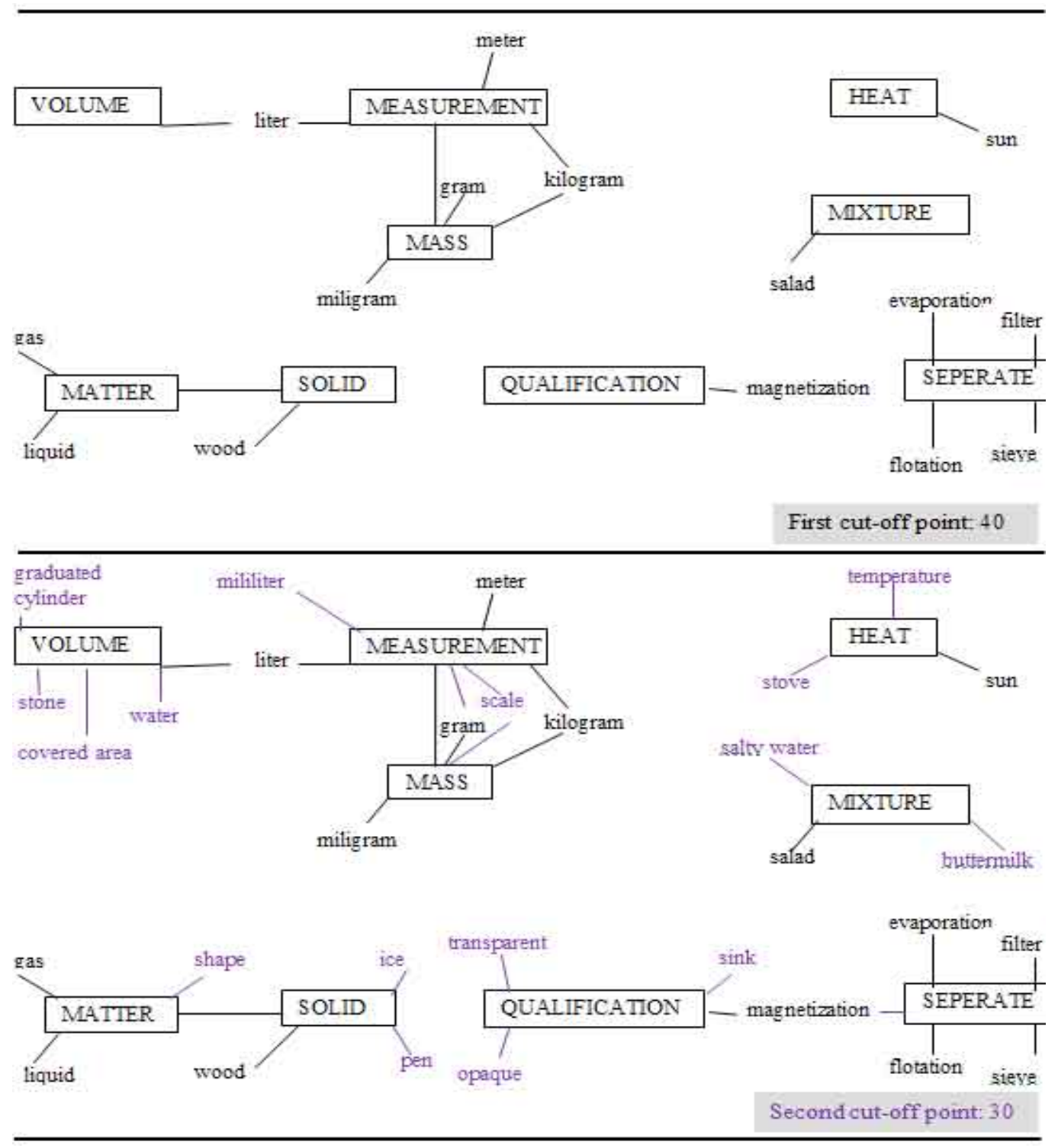

Figure 2: Mind maps of students in the experimental group determined through the post-WAT. 


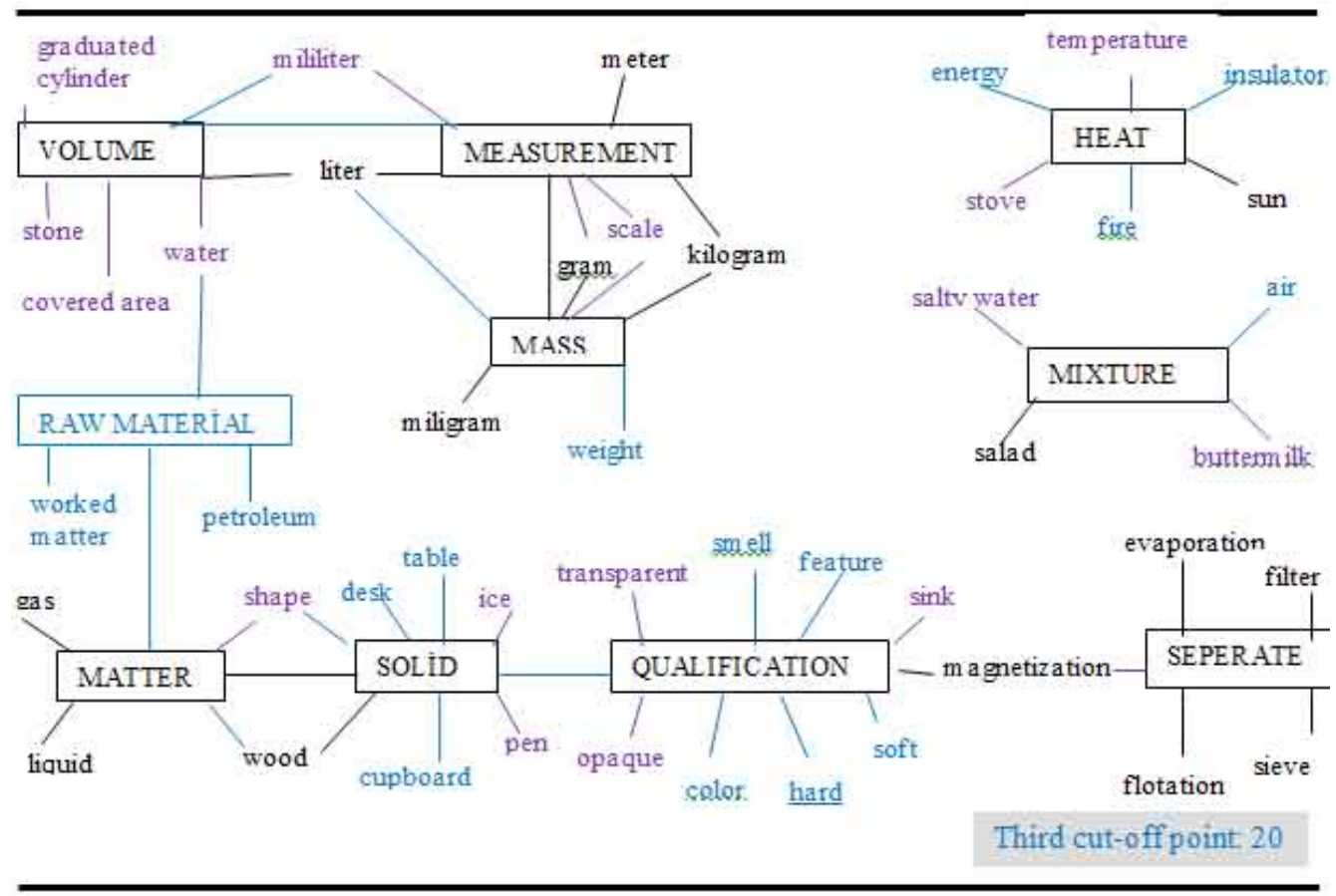

Figure 2 (continue): Mind maps of students in the experimental group determined through the post-WAT.

The mind maps of students in the control group determined through pre-WAT are shown in Figure 3. The results in Figure 3 have been interpreted as follows;

a) In the first CoP, 3 in 10 concepts emerged. The concept MASS and MEASUREMENT were associated with word "kilogram". One word (SOLID-ice; MASS-kilogram) or two words (MEASUREMENT-meter and kilogram) recalled of each concept.

b) In the second CoP, The concept QUALIFICATION and HEAT were added in mind map. Written words most commonly used and easily recalled words concepts in daily life as ice, stove and meter

c) In the third CoP, 6 in 10 concepts emerged by adding MIXTURE concept. The concepts usually were associated with one or two concepts. The concepts that excepted MASS and MEASUREMENT weren't associated each other. Words associated with concepts to be noted that the words used interchangeably in daily life such as MASS-weight, HEAT-temperature, QUALIFICATION-feature and MIXTURE-mixing.

Mind maps of the students in control group determined through post-WAT are shown in Figure 4. The results in Figure 4 have been interpreted as follows;

a) In the first CoP, 8 in 10 concepts which except RAW MATERIAL and VOLUME were emerged in mind map. MEASUREMENT and MASS were associated with each other; also MATTER and SOLID were associated. Every concept was associated with more than one word.

b) In the first CoP, 8 in 10 concepts which except RAW MATERIAL and VOLUME were emerged in mind map. MEASUREMENT and MASS were associated with each other; also MATTER and SOLID were associated. Every concept was associated with more than one word.

c) In the second CoP, RAW MATERIAL was added to emerge concepts. The numbers of words associated with each concept were increased. Words associated with concepts have reflected feature or state or example of the concept.

d) In the third CoP, all of the concepts were raised by adding VOLUME. MEASUREMENT and MASS were associated and RAW MATERIAL, MATTER concepts were associated but another concept 
wasn't associated with each other. The numbers of words associated with the concepts have been increased; even reaching 6 or 7 numbers. But the concepts were independent from each other as Information Island in mind map.

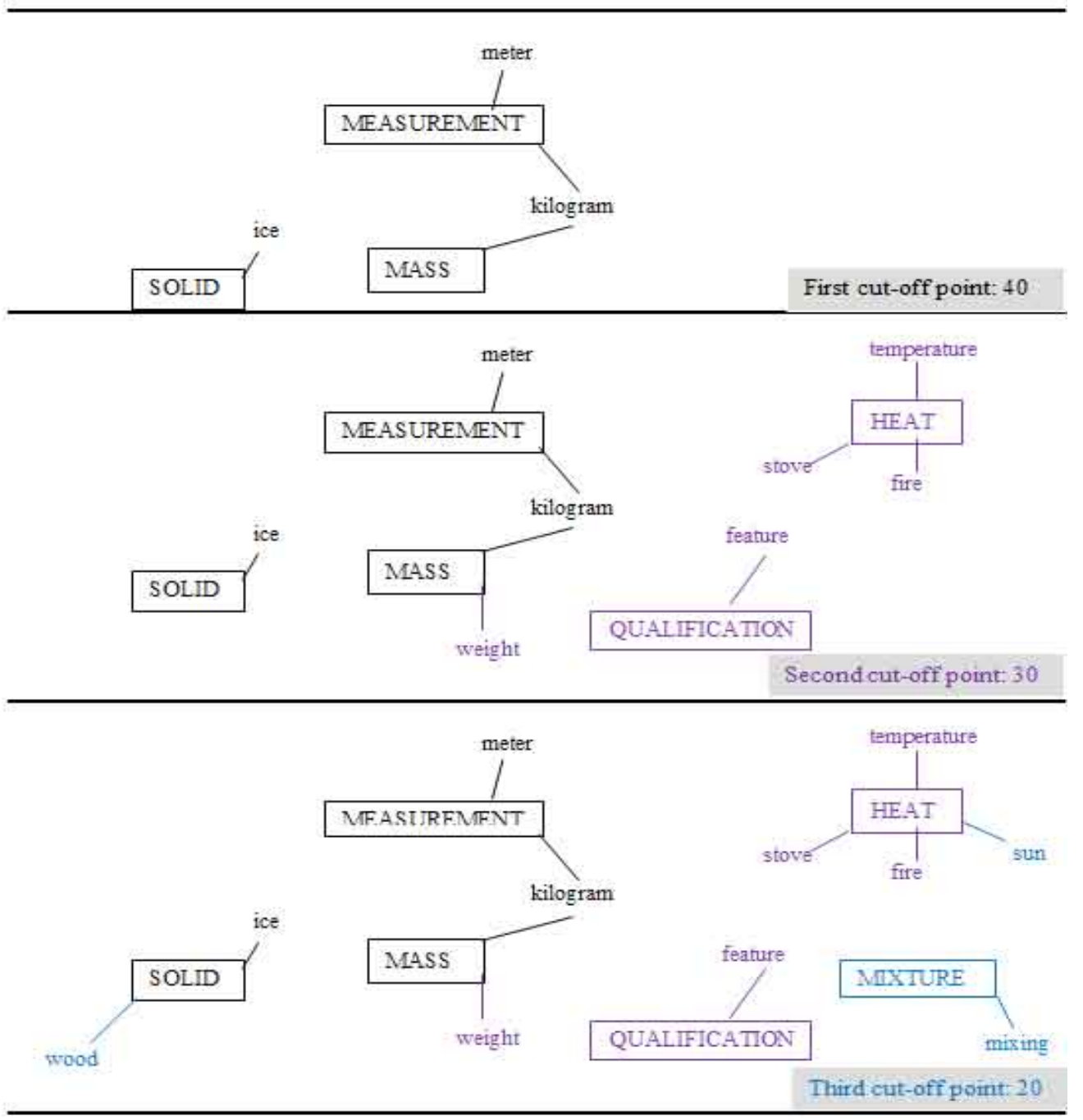

Figure 3: Mind maps of students in the control group determined through the pre-WAT.

The first CoP in the post-WAT has raised more concepts than the pre-WAT and in all CoP. The number of words associated with concepts in the post-WAT was higher than in the pre-WAT. However, the concepts were not associated with each other.

The concept MATTER was not associated with any word frequency 20 and over in the pre-WAT but appeared with the words gas, liquid and solid in the first CoP of the post-WAT.The concepts that appeared after the second $\mathrm{CoP}$ in the pre-WAT have emerged in the first CoP in the post-WAT. The concept MIXTURE that appeared in the third CoP of the pre-WAT has emerged with examples from daily life under the first CoP of the post-WAT such as salad, salty water and buttermilk. The SEPARATE concept did not appear in the pre-WAT but appeared as associated with words filter, flotation and evaporation in the post-WAT.

Branching in mind map was increased by adding new words to the concepts in the post-WAT. The concepts in the pre-WAT and the post-WAT were not associated with any concepts and were left as an information island mind map. 
The misconceptions that emerged in the pre-WAT have also emerged in the first CoP in the postWAT (as MASS-weight).

Considering the pre-WATs of the control and experimental groups (Figure 1 and 3), we see that the number of emerging concepts and words is nearly the same. Also the number of relevant and irrelevant words and misconceptions is the same.

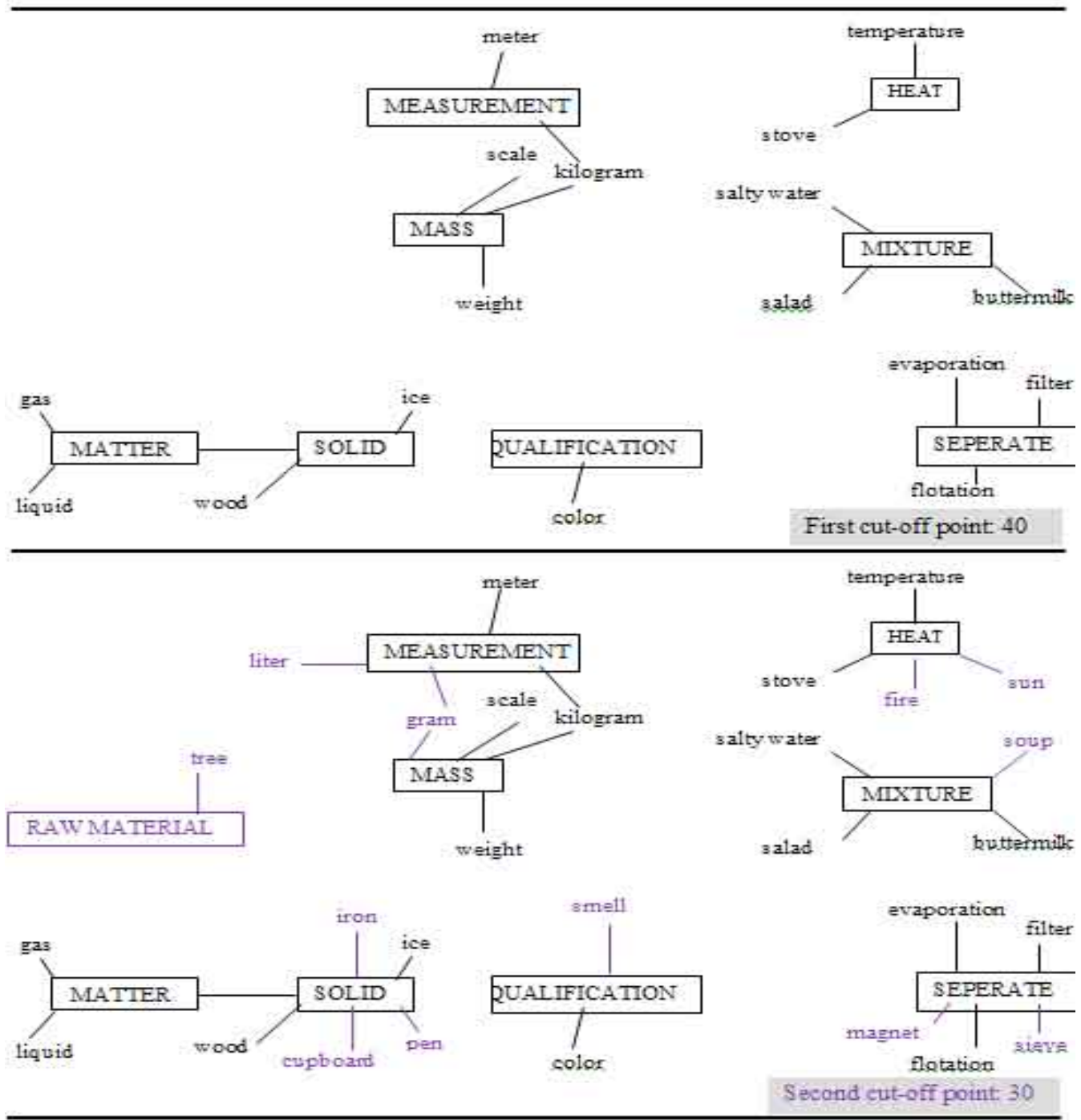

Figure 4: Mind maps of students in the control group determined through the post-WAT.

The first CoP in the post-WAT in the experimental group has raised more concepts and also in all CoPs. The number of words associated with concepts in the experimental group was higher than in the control. While the concepts were associated with each other in the experimental group, they weren't in the control group.

In the experimental group, QUALIFICATION concept was associated with a word more often than in the control group. The liter or milliliter words associated with VOLUME concept in the experimental group were not associated with in the control group. Not associating these concepts, directly linked with the concept VOLUME, can be interpreted in the way that students in the control group have not fully understood the key concept of volume yet. The concept SEPARATE was associated with the word magnetization and 
thus the branching increased in the control group. However, word magnetization, one of the features in differentiating the matters was not associated with the concept QUALIFICATION. The concept SEPARATE was left as an information island in the mind map. Considering the experimental group, it is seen that the variety of the words associated with the concept QUALIFICATION is insufficient in the control. The words sink, soft, hard, opaque, transparent, magnetization were used in the experimental group in addition to the control group, and the word magnetization was associated with the key concept SEPARATE. The concept VOLUME appearing for the first time under the third CoP was associated with the words space, stone, graduated container, and covered area it occupies. It is interesting that writing the materials (stone, graduated container), regarding the method of outpouring used in measuring the volume of the container without shape do not associate them with the concept VOLUME. This concept was associated with RAW MATERIAL, MEASUREMENT and MASS concepts in mind map of the experimental group but the VOLUME concept is left as an information island in the control group.

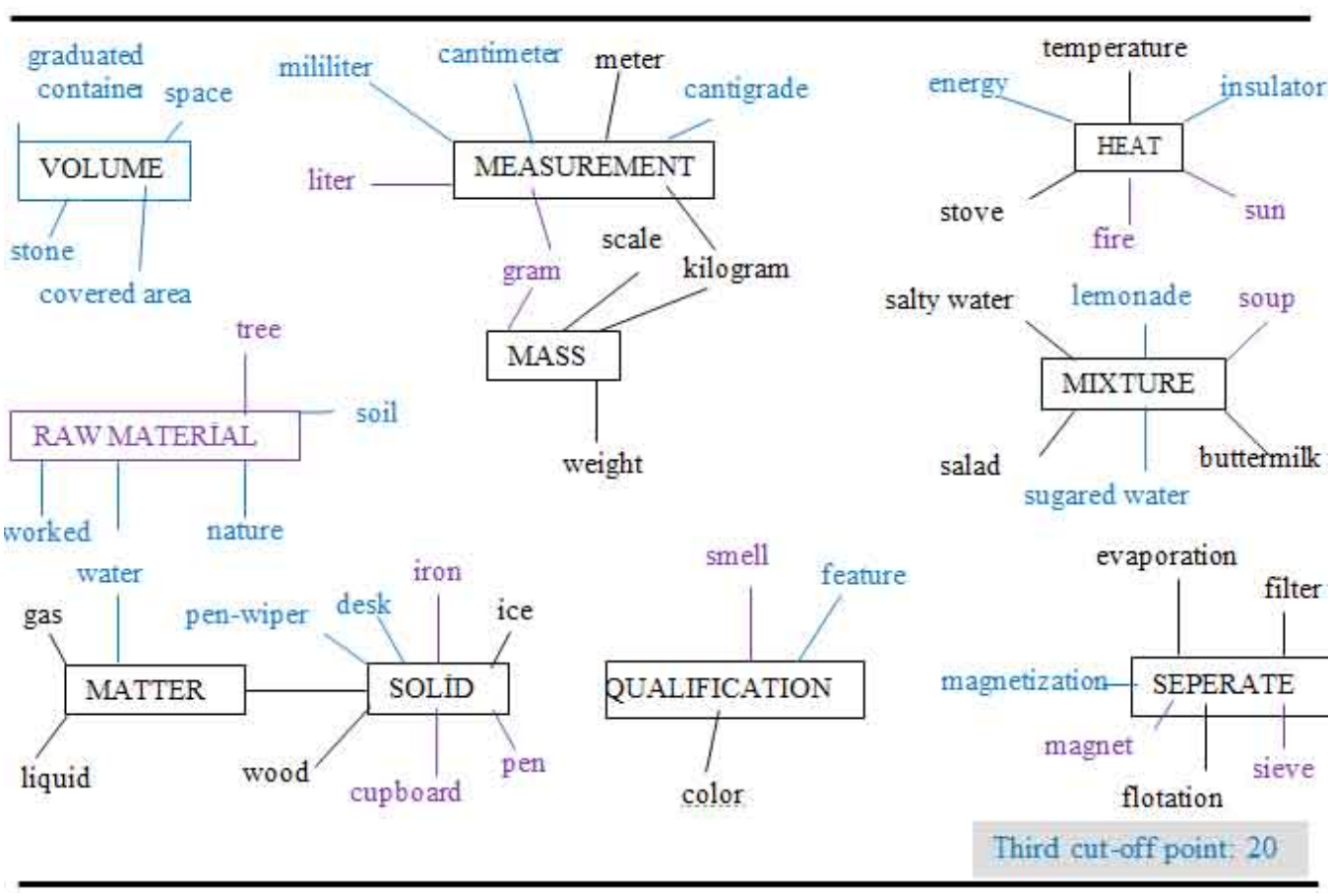

Figure 4 (continue): Mind maps of students in the control group determined through the postWAT.

\section{Discussion}

The main purpose of this study is to compare the effect of 5 E learning cycle and traditional instruction on $4^{\text {th }}$ grade students' mental ability in the unit of "Introduction to Matter". The main difference between the two teaching methods is that the students in the experimental group followed pre-prepared material based on the 5 E learning cycle while the ones in the control group received the same information with a traditional teaching method. It is important that the main concepts be settled in the minds of students according to student-centered approaches. However, determining and evaluating the structures of the mind is very difficult. WAT allows us to put forward the relationship between concepts.

According to the data obtained from the pre- to post-WAT for the first and the second research questions of the study, teaching methods caused to increase kinds and frequencies in relevant words and to decrease kinds and frequencies in irrelevant words. However, 5E learning cycle is more effective both to 
increase kinds and frequencies in relevant words' and to decrease kinds and frequencies in irrelevant words' than the traditional teaching method. This result is consistent with the results presented by Cardelini and Bahar (2000), Tongaç (2006) and Çetin (2010). The relationship between the phases of $5 E$ learning cycle model enhances students' conceptual comprehension, promotes knowledge transformation and recalls information among students, thus they remember more relevant words and kinds related concepts in the subject of matter. In general, it is seen that students in the experimental group are much more successful than students in the control group in terms of scientific words written for the key concepts.

The mind maps were drawn based on the pre- and post-WAT for the third and fourth research questions. The results showed that students in the experiment and control groups created similar mind maps in the pre-WAT. Some of the key words did not appear in the mind maps and some of the key words are present in the mind maps as Information Island without relation with any concepts or words. More concepts emerged and the numbers of words associated with the concepts from the pre-WAT to the post-WAT increased in the groups. Comprehension of the concepts in both groups increased but the number of words associated with the concepts was greater, and the number of concepts associated with each other from the pre- to post-WAT was higher in the experimental group than in the control group. In other words, there were more associated concepts in the $5 \mathrm{E}$ learning cycle model.

When the post-WAT mind maps are compared in the experiment and the control groups for the fifth research question, it can be seen that the mind maps of the experimental group implementing $5 \mathrm{E}$ learning model, key concepts and words within the scope of "Introduction to Matter" unit are more linked, branched as a whole in comparison with the mind maps of the control group implementing traditional teaching method. Students in the control group and the experimental group associated nearly the same concepts with the key concepts in the post-WAT mind map but the control group left these concepts and words as independent information islands and they did not constitute meaningfully as a whole in students' minds.

There is consistency between the findings in our study and the previous studies in that instruction based on 5 E learning cycle can facilitate learning of scientific concepts (Boddy et al. 2003; Campell, 2000; Ceylan \& Geban, 2009; Coulson, 2002; Liu, Peng, Wu, \& Lin, 2009; Musheno \& Lawson, 1999; Tural, Akdeniz, \& Alev, 2010). 5E learning cycle is a dynamic and interactive process. In this model, changing and improving conceptions in students' minds frequently show students inadequacies of their current concepts and challenge them about these concepts. In 5 E learning cycle, teacher takes students' prior knowledge into account and helps them to get accustomed with the new knowledge. When the prior conceptions are inconsistent, it is very difficult to understand concepts in a meaningful way. Thus, designing activities appropriate to student level is really important as emphasized in $5 \mathrm{E}$ learning cycle model. Furthermore, other important points are revealing students' mind structures and maintaining integrity of the concepts. In this study, apart from the findings of other studies, it was found out that $5 E$ learning model is effective in establishing the relationship among concepts.

\section{Conclusions}

One of the most important goals in science education is developing students' conceptual understanding. Students' conceptual understanding in most previous study related 5E Learning Cycle measured with multiple-choice tests but students' conceptual understanding in this study measured with word association test. The word association test is one of the techniques that reveal the connections of the information among each other in students' minds and newly-created information network, and that show if the relationship between pre-existing concepts and newly-gained knowledge is significant (Bahar et al. 1999). The results of this study showed that students' understanding of concepts in the unit of "Introduction to the Matter", both in the experiment and the control groups is higher in the post-WAT than in the pre-WAT. As a result, this increase is more significant in the experimental group for kinds and frequencies in relevant words and the numbers of words associated with the concepts. Hence, it is proved that students in the experimental group learnt terms in a more meaningful and more interrelated way than students in the control group. For these reasons, teachers should endeavour to use the $5 \mathrm{e}$ learning cycle in their lessons to make connections between concepts and to ensure the integrity of concepts in students' mind. 
References

Atay, D. P., \& Tekkaya, C. (2008). Promoting students' learning in genetics with the learning cycle. The Journal of Experimental Education, 76 (3), 259-280.

Bahar, M., Johnstone, A. H., \& Sutcliffe, R. G. (1999). Investigation of students' cognitive structure in elementary genetics through word association tests. Journal of Biological Education, 33 (3), 134-141.

Bahar, M., Nartgün, Z., Durmuş, S., \& Bıcak, B. (2008). Geleneksel-Alternatif ölçme ve değerlendirme. (2. Baskı). Ankara: Pegem Akademi. [Dictionary of the Turkish language]

Ben-Zvi, R., Eylon, B., \& Silberstein, J. (1986). Is an atom of copper malleable? Journal of Chemical Education, 63, 6466.

Boddy, N., Watson, K., \& Aubusson, P. (2003). A trial of the five Es: A referent model for constructivist teaching and learning. Research in Science Education, 33, 27-42.

Bonder, G. M. (1986). Constructivism: A theory of knowledge. Journal of Chemical Education, 63, 873-878.

Brooks, J. G., \& Brooks, M. G. (1999). Becoming a constructivist teacher (in search of understanding, the case of constructivist classrooms). Association for supervision and curriculum development (ASCD). Alexandria. USA.

Bybee, R. (2006). Enhancing science teaching and student learning: A BSCS perspective. Paper presented at the ACER Research Conference 2006. Retrieved 13-10-2012, from http://www.acer.edu.au/documents/RC2006_Bybee.pdf.

Cachapuz, A. F. C., \& Maskill, R. (1987). Detecting changes with learning in the organization of knowledge: Use of word association test to follow the learning of collision theory. International Journal of Science Education, 9, 491-504.

Campbell, M. A. (2000). The effects of the 5E learning cycle model on students' understanding of force and motion concepts. Unpublished master thesis, Florida. Millersville University.

Cardelini, L., \& Bahar, M. (2000). Monitoring the learning of chemistry through word association tests. Australian Chemistry Resource Book, 19, 59-60.

Ceylan, E., \& Geban, Ö. (2009). Facilitating conceptual change in understanding state of matter and solubility concepts by using 5 E learning cycle model. Hacettepe University Journal of Education, 36, 41-50.

Clark, I. (2003). Soils ain't soils. Investigating: Australian Primary \& Junior Science Journal, 19 (4), 13-16.

Coulson, D. (2002). BSCS Science: An Inquiry Approach- 2002 Evaluation Findings. Arnold, MD: PS International: 2002

Çetin, A. (2010). Fen ve Teknoloji Dersinde Iş̧birlikli Öğrenme Tekniklerinin Öğrencilerin Başarı, Tutum ve Zihinsel Yapılarına Etkisi. Unpublished Master Thesis, Hatay. Mustafa Kemal University, [Dictionary of the Turkish language].

Demircioğlu, G., Özmen, H., \& Demircioğlu, H. (2004). Bütünlestirici öğrenme kuramına dayalı olarak geliştirilen etkinliklerinin uygulanmasının etkililiğinin araştırılması. Türk Fen Eğitimi Dergisi (TUFED), 1(1), 21-34. [Dictionary of the Turkish language].

Evans, C. (2004). Learning with inquiring minds, students are introduced to the unit on gas laws and properties of gases using the $5 \mathrm{E}$ model. The Science Teacher, 71 (1).

Frank, M., \& Barzilai, A. (2004). Integrating alternative assessment in a project-based learning course for pre-service science and technology teachers. Assessment \& Evaluation in Higher Education, 29 (1), 41-61.

Gibbons, B. A. (2003). Supporting elementary science educations for English learners, a constructivist evaluation instrument. The Journal of Educational Research, 96 (6), 371-380.

Gupta, M. L. (2004). Enhancing student performance through cooperative learning in physical sciences. Assessment \& Evaluation in Higher Education, 29 (1), 63-73.

Hirsh, K. W., \& Tree, J. J. (2001). Word association norms for two cohorts of British adults. Journal of Neurolinguistics, $14,1-44$.

Hovardas, T., \& Korfiatis, K. J. (2006). Word associations as a tool for assessing conceptual change in science education. Learning and Instruction, 16, 416-432.

Isa, A. M., \& Maskill, R. (1982). A comparison of science word meaning in the classrooms of two different countries: Scottish integrated science in Scotland and in Malaysia. British Journal of Educational Psychology, 52, 188-198.

Karamustafaoğlu, S., \& Yıldız, B. (2006). Fen ve teknoloji öğretiminde yapılandırıı yaklaşımla geliştirilmiş etkinliklerin değerlendirilmesi. VII. Ulusal Fen Bilimleri ve Matematik Eğitimi Kongresi, Ankara, Gazi University. [Dictionary of the Turkish language].

Kostova, Z., \& Radoynovska, B. (2010). Motivating students' learning using word association test and concept maps. Bulgarian Journal of Science and Education Policy (BJSEP), 4 (1), 62-98.

Krajcik, J. S., Blumenfeld, P. C., Marx, R. W., \& Soloway, E. (1994). A collaborative model for helping middle grade science teachers learn project-based instruction. Elementary School Journal, 94 (5), 483-497.

Krnel, D., Glažar, S., \&Watson, R. (2003). The development of the concept of "matter": A cross-age study of how children classify materials. Science Education, 87, 621- 639.

Krnel, D., Watson, R., \& Glažar, S.A. (2005). The development of the concept of 'matter': A cross囚age study of how children describe materials, International Journal of Science Education, 27 (3), 367-383.

Lawson, A. E. (1995). Science teaching and the development of thinking. Belmont, CA: Wadsworth Publishing Company. 
Liu, T. C., Peng, H., Wu, W. H., \& Lin, M. S. (2009). The effects of mobile natural-science learning based on the 5 E learning cycle: A case study. Educational Technology \& Society, 12 (4), 344-358.

Marx, R. W., Blumenfeld, P. C., Krajcik, J. S., Fishman, B., Soloway, E., Geier, R., \& Tal, R.T. (2004). Inquiry-based science in the middle grades, assessment of learning in urban systemic reform. Journal of Research In Science Teachıng, 41 (10), 1063-1080.

Miles, M. B., \& Huberman, A. M. (1994). Qualitative data analysis. SAGE Publication, Inc. California.

Musheno, B. V., \& Lawson, A. E. (1999) Effects of learning cycle and traditional text on comprehension of science concepts by students at differing reasoning levels. Journal of Research in Science Teaching, 36 (1), 23-37.

Nakiboğlu, C. (2008). Using word associations for assessing non major science students' knowledge structure before and after general chemistry instruction: The case of atomic structure. Chemistry Education Research and Practice, 9, 309-322.

Özmen, H. (2004). Fen öğretiminde öğrenme teorileri ve öğrenmeye bütünleştirici (constructivist) bakış. The Turkish Online Journal of Educational Technology (TOJET), 3 (1), 100-111. [Dictionary of the Turkish language].

Özmen, H. (2011). Turkish primary students' conceptions about the particulate nature of matter. International Journal of Environmental \& Science Education, 6 (1), 99-121.

Palmer, D. H. (2003). Investigating the relationship between refutational text and conceptual change. Science Education, 87, 663-684.

Peterson, R. F., \& Treagust, D. F. (1998). Learning to teach primary science through problem-based learning. Science Education, 82, 215-237.

Pozo, J. I., \& Crespo, M. A. G. (2005). The embodied nature of ımplicit theories: The consistency of Ideas about the nature of matter. Cognition and Instruction, 23 (3), 351-387.

Saribas, D., Mugaloglu, E.Z., \& Bayram, H. (2013). Creating Metacognitive Awareness

in the Lab: Outcomes for Preservice Science Teachers. Eurasia Journal of Mathematics, Science \& Technology Education, 9, 83-88.

Schlenker, R. M., Blanke, R., \& Mecca, P. (2007). Using the 5E learning cycle sequence with carbon dioxide. Science Activities: Classroom Projects and Curriculum Ideas, 44 (3), 83-94.

Smerdan, B. A., \& Burkam, D. T. (1999). Access to constructivist and didactic teaching, Who gets it? Where is it practiced? Teachers College Record, 101 (1), 5.

Stamp, N., \& O'Brien, T. (2005). GK-12 partnership: A model to advance change in science education. Bio Science, 55 (1), 70-77.

Tongaç, E. (2006). Farklı öğretim yaklaşimlarinin öğrencilerin fen bilgisi dersi dolaşim sistemi konusundaki bilişsel yapilarina etkilerinin araştirilmasi. Unpublished Master Thesis, Bolu. Abant İzzet Baysal University. [Dictionary of the Turkish language].

Tural, G., Akdeniz, A.R., \& Alev, N. (2010) Effect of 5E teaching model on student teachers' understanding of weightlessness. Journal Science Education Technology, 19, 470-488.

Valanides, N. (2000). Primary student teachers' understanding of the process and effects of distillation. Chemistry Education: Research and Practice in Europe, 1 (3), 355-364.

Wagner W., Valencia, J., \& Elejabarieta, F. (1996). Relevance, discourse and the "hot" stable core of social representation- a structural analysis of word association. British Journal of Social Psychology, 35, 331-352.

Wilder, M., \& Shuttleworth, P. (2004). Cell inquiry: A 5E learning cycle lesson. Science Activities, 41 (1), 25-31.

Wright, E.I. (1995). Discrepant event demonstrations: Motivating students to learn science concepts. The Science Teacher, 15, 25-28.

Ibrahim Bilgin

\section{Hümeyra} Coşkun

Idris Aktaş
PhD., Associate Professor, Mustafa Kemal University, Faculty of Education, Department of Primary Science Education, 31000 Antakya-Hatay, Turkey. Phone: +90 3262456006 Ext: 5402.

Fax: +902456005 .

Email: ibilgin66@yahoo.com

Chemistry Teacher, Antakya Anatolian High School, 31000 Antakya-Hatay, Turkey.

Email: humeyracoskun@yahoo.com

Research Assistant, Mustafa Kemal University, Faculty of Education, Department of Primary Science Education, 31000 Antakya, Hatay, Turkey. Email: idrisaktas2560@hotmail.com 